\title{
Physicochemical Nutritional and Sensory Properties of Kluiklui Supplemented with Porang Glucomannan and Banana Flour
}

\author{
Nasser Farid Geraldo ${ }^{1)^{*}}$, Agnes Murdiati ${ }^{1)}$, Eni Harmayani ${ }^{1)}$ \\ ${ }^{1)}$ Department of Food and Agricultural Product Technology, Faculty of Agricultural Technology, \\ Universitas Gadjah Mada, Yogyakarta, Indonesia \\ *) Correspondence Email: eniharmayani@ugm.ac.id
}

\begin{abstract}
The meal from peanut oil extraction may be valorized as snacks for human food. In Benin, West Africa, this peanut meal is traditionally used to produce snack food called kluiklui. The snacks were obtained by frying partially defatted peanut paste rolled into sticks. In order to improve the sensory, physicochemical, and nutritional content of kluiklui, different types of flour enriched kluiklui (FEK) were produced by incorporating native banana flour or type-3 resistant starch banana flour at two levels (4 and $5 \%$ ) and $1 \%$ porang glucomannan (mass basis) in this study. The produced kluiklui were evaluated for physicochemical, sensory and nutritional properties and were compared with a control kluiklui made from $100 \%$ partially defatted peanut paste. The samples with $1 \%$ porang glucomannan and those with the combination of $4 \%$ type- 3 resistant starch banana flour and $1 \%$ porang glucomannan achieved the highest consumer acceptance with overall acceptability value 5.53 and 5.40, respectively. The developed products were found to be highly nutritious in terms of protein and carbohydrates. However, the products had a higher value of moisture content and required further drying. The indigestible fraction was also increased in the formulated kluiklui, which is attributed to the synergistic presence of fiber. Sample containing 4\% type-3 resistant starch banana flour and 1\% porang glucomannan exhibited the highest indigestible fraction content $(30.76 \%)$. Our results showed that the nutritionally and sensory accepted flour enriched kluiklui can be prepared using banana flour and porang glucomannan.
\end{abstract}

Keywords: kluiklui, flour-enriched kluiklui, banana flour, porang glucomannan, indigestible fraction

\section{INTRODUCTION}

Snack foods are reasonably priced and alternatives to homecooked foods. Furthermore, they are convenient and economical for a busy lifestyle. Snacks exist in several forms and meet specific needs according to their composition (Agbaje et al., 2014; Khouryieh \& Aramouni, 2013), so it is gaining prominence amongst youth and younger generations and is becoming an important part of life. Nowadays, the demand for functional products, especially those rich in indigestible fiber, is increasing.

The partially defatted peanut paste developed from crushed peanut provides a high-protein food ingredient for snack formulation. Partially defatted peanuts paste is very low in saturated fat and cholesterol (Fekria et al, 2012). In developing countries of West Africa as well as Benin, the partially defatted peanut paste is transformed into kluiklui, a snack produced using traditional technology by women from Agonli, central Benin -'(Sanya et al., 2013; Sanya et al., 2015; Videgla et al., 2016). Homemade kluiklui is very popular among the population. Naturally, it is tasty. Depending on the ingredients added, kluiklui may taste sweet or salty, has a long shelf life, and is relatively low cost.

The traditional indigestible substance in food is not the portion of the indigestible fraction (IF) represented but all substances that can reach the colon intact and facilitate the fermentative microflora (Saura-Calixto et al., 2000). Acceptable kluiklui can also be made by incorporating maize flour at the level of 5 percent (Sanya, et al., 2013; Sanya et al., 2015) to maintain its quality aspects. Enriching the kluiklui with an indigestible fraction remains a significant idea to improve the consumer's health and help avoid chronic diseases.

Unripe banana flour (UBF) is a suitable substitute in the pro- duction of snacks because of its nutritional/nutraceutical potential and represents an alternative source of indigestible carbohydrates and antioxidant compounds. reported the beneficial effects of this flour on human health, associated with indigestible components such as resistant starch. Resistant starch provides a better appearance, texture, and mouthfeel than conventional fibers to food products . However, considering the heat sensitivity of a native source of resistant starch, the use of a thermostable resistant starch source, in this case, type-3 resistant starch of banana flour, will be beneficial to increase the concentration of resistant starch in the final product.

Porang glucomannan is a viscous neutral dietary fiber extracted from Amorphophallus oncophyllus or Porang tubers (Harmayani et al., 2014). Porang glucomannan is also advantageous due to one of its primary benefits as an indigestible dietary fiber (Chua et al., 2010). Porang glucomannan, with a solubility of $86.43 \%$ and a high viscosity (Harmayani et al., 2014), could inhibit the growth of certain bacteria (Harmayani et al., 2014). Due to its health benefits and functional properties, porang glucomannan can be added to many foods applications. Glucomannan was incorporated in pudding and noodles at 1 , and 2 percent level, and quality attributes were found to be improved along with the fiber content and the texture (Cui et al., 2019; Xiong et al., 2009; Yun Zhou et al., 2013).

Nowadays, the development and production of fiber-enriched products help reduce the deficit of fiber intake in the consumer's diet. Kluiklui, a protein-rich source food, is less in indigestible fraction. Potential fiber sources for fiber-enriched dietetic food products are very diverse. The excellent source of fiber such as banana flour and porang glucomannan were tested and proven as possible fiber sources in food products. Banana flour and porang glucomannan can help in the challe- 
es of the development of fiber-enriched dietetic products. Replacement of a part of partially defatted peanut paste as the basic kluiklui constituent with fiber-rich raw materials will also reflect the interactions of kluiklui constituents. Besides the basic dietetic gastrointestinal effect, it will help to improve the nutritional composition of the original kluiklui and increase the rate of indigestible fractions. This study was conducted to develop and evaluate different types of flourenriched kluiklui by incorporating unripe banana flour, type3 resistant starch banana flour, and porang glucomannan in the partially defatted peanut paste for nutritional and health benefits.

\section{MATERIALS AND METHODS}

\section{Source of Raw Material}

Peanuts were purchased from the local market of Kolombo, Yogyakarta, Indonesia. Unripe banana flour and sugar were purchased from a local store (Yogyakarta, Indonesia). Porang glucomannan was kindly provided by Team Glucomannan (Faculty of Agricultural Technology/Universitas Gadjah Mada, Yogyakarta, Indonesia). The ingredients used were all food-grade and the chemicals were analytical grade.

\section{Preparation of Type-3 Resistant Starch Banana Flour}

The unripe banana flour was transformed into type-3 resistant starch banana flour (BFRS3) using the method described by Aparicio-Saguilán et al., (2005) with slight modifications, which consists of a combination of 3 cycles of autoclaving cooling. In this method, the autoclaving process is carried out at $121^{\circ} \mathrm{C}$ for 1 hour, which was then followed by cooling in a freezer at $4^{\circ} \mathrm{C}$ for 24 hours.

\section{Preparation of Partially Defatted Peanut Paste}

Partially defatted peanut paste was obtained after the peanut was de-shelled, roasted, de-skinned, and grounded with a food processor. Afterward, the oil was extracted manually by squeezing.

\section{Development and Standardization of Products}

Kluiklui were prepared using partially defatted peanut paste made from the whole peanut. Different types of flour-enriched kluiklui (Figure 2) were prepared in the incubator laboratory of the Department of Food and Agricultural Product Technology, Universitas Gadjah Mada. A total of 6 formulations were developed. These products were prepared using standardized ingredients and different formulas (Table 1). The flowchart diagram of kluiklui can be seen in Figure 1. All ingredients were mixed manually. After 3 minutes of mixing, we had total incorporation, and then the dough was sheeted to $5 \mathrm{~mm}$ thickness and cut by pressing molds onto a circular dough sheet. Frying was performed thoroughly in extracted peanut oil for $8 \mathrm{~min}$. After cooling for 1 hour to room temperature, produced kluiklui were wrapped in plastic bags.

Table 1. Standardized ingredients used for preparing different kluiklui sample

\begin{tabular}{lllllll}
\hline Ingredients & \multicolumn{6}{c}{ Sample formulation } \\
\hline & Control & \multicolumn{5}{c}{ Kluiklui with incorporation } \\
\cline { 2 - 7 } & \multicolumn{1}{c}{ K } & FEK1 & FEK2 & FEK3 & FEK4 & FEK5 \\
\hline DPP (\%) & 100 & 99 & 95 & 95 & 95 & 95 \\
G (\%) & - & 1 & - & - & 1 & 1 \\
UBF (\%) & - & - & 5 & - & 4 & - \\
BFRS3 (\%) & - & - & - & 5 & - & 4 \\
Sugar (g) & 28 & 28 & 28 & 28 & 28 & 28 \\
\hline
\end{tabular}

Notes:

$\mathrm{K}=100 \%$ partially defatted peanut paste, FEK 1 = with $1 \%$ of glucomannan, FEK 2 : with $5 \%$ of unripe banana flour, FEK $3=$ with $5 \%$ of RS-3 banana flour, FEK $4=$ with $4 \%$ of unripe banana flour and $1 \%$ of glucomannan, FEK $5=$ with $4 \%$ of RS-3 banana flour and $1 \%$ of glucomannan. $\mathrm{DPP}=$ partially defatted peanut paste; $\mathrm{G}=$ glucomannan, $\mathrm{UBF}=$ unripe banana flour, BFRS3 = type 3 resistant starch banana flour

\section{Texture Characteristics}

The texture characteristics of samples in terms of hardness and the fracturability were measured using a Stable Micro Systems TA-XT Plus texture analyzer (Serial No. 5014, England) fitted with a $25 \mathrm{~mm}$ cylinder probe. The force-time for hardness value was considered the area under the curve obtained, and the linear distance was taken as an indication of fracturability that helped reach the peak. The studies were conducted at a test speed of $2 \mathrm{~mm} / \mathrm{s}$ with a delay $30 \mathrm{~s}$ between the first and second compression (Kaur et al. 2018).

\section{Color Determination}

The color was evaluated by the CIE LAB system (Chroma Meter CR-400, Minolta LTD Japan). The results were expressed in accordance with the CIE LAB system, in which $L^{*}$ represented lightness, $a^{*}$ represented redness, while $b^{*}$ represented yellowness (Mahloko et al., 2019). Numerical total color difference $(\Delta \mathrm{E})$ values were also measured as suggested, and all color values were recorded in triplicates for each sample. Based on the obtained values of $L^{*}, a^{*}$, and $b^{*}$, the hue angle, $\mathrm{h}^{\circ}$, was also calculated. By using the following equation:

$\mathrm{h}^{\circ}=\tan ^{-1} \frac{\mathrm{b}^{*}}{\mathrm{a}^{*}}$

\section{Nutritional evaluation of products}

The samples were nutritionally evaluated for their proximate like moisture, protein, fat, ash, and energy content on a dry basis by using standardized methods of the Association of Analytical Communities (AOAC) described by Barreira et al., (2019). The Carbohydrate content of the developed products was determined by subtracting the total values of proximate composition from 100.

\section{Sensory evaluation of products}

Sensory evaluation was done as described by Iwe (2014). 30 untrained panelists (research students) from Department of Food and Agricultural Product Technology, Universitas 
Gadjah Mada were required to observe the sample, taste, and score. The panelist rinsed their mouth with water before tasting another sample. The samples were evaluated for their sensory acceptability. These attributes such as color, appearance, flavor, texture, taste, and overall acceptability were assessed using a seven-point hedonic rating scale.

\section{Determination of the indigestible fraction}

In order to estimate the indigestible fraction content, Soluble (SIF) and insoluble (IIF) indigestible fractions were assessed by using the method of Saura-Calixto et al., (2000) with a slight modification. The total indigestible fraction (TIF) was calculated as IIF+SIF. In brief, $300 \mathrm{mg}$ of sample were added to $0.2 \mathrm{ml}$ of a pepsin solution containing $1 \mathrm{~g}$ of pepsin $/ 10 \mathrm{ml}$ of $\mathrm{KCl}-\mathrm{HCl}$ buffer at $\mathrm{pH}$ 1.5. Samples were incubated for $1 \mathrm{~h}$ at $40^{\circ} \mathrm{C}$ in a water bath with constant shaking. Then, $9 \mathrm{ml}$ of Tris-maleate buffer $(0.1 \mathrm{M}, \mathrm{pH}$ 6.9) was added and the $\mathrm{pH}$ was measured. $\alpha$-amylase, $1 \mathrm{ml}$ of a $40 \mathrm{mg} / \mathrm{ml}$ solution in Tris-maleate buffer was added, and the samples were incubated in a water bath at $37^{\circ} \mathrm{C}$ for $16 \mathrm{~h}$ with constant shaking. Samples were filtered through celite as the filter aid, and supernatants were removed. Residues were washed twice with $10 \mathrm{ml}$ of distilled water and all supernatants combined. The residues were dried overnight at $105^{\circ} \mathrm{C}$ and quantified gravimetrically as the IIF. Ethanol was added to supernatants for precipitation, and then the residue obtained after precipitation was dried overnight at $105^{\circ} \mathrm{C}$ and quantified gravimetrically as the SIF. The analysis was performed in triplicate.

\section{Statistical analysis}

Means and standard deviations of all replicates were calculated for every analysis in the present study. The significant difference of mean values was determined with one-way analysis of variance (ANOVA) followed by Duncan's multiple range test using the commercial statistical software package SPSS ver.24 at a significance level of ( $p<$ $0.05)$.

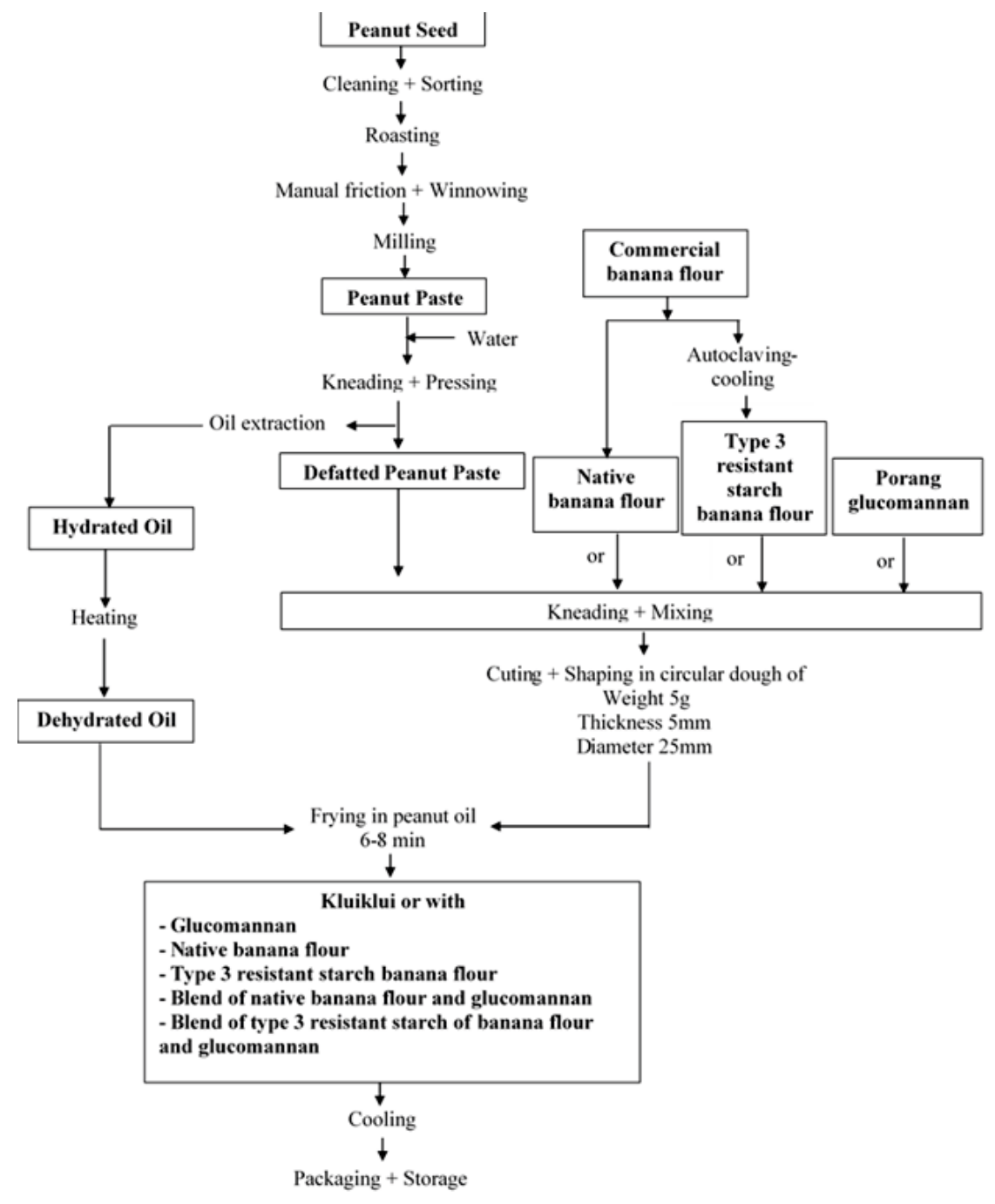

Figure 1. Flowchart diagram with condition of process.

\section{RESULT AND DISCUSSION}

\section{Product quality}

The developed products obtained by adding banana flour and porang glucomannan in partially defatted peanut paste were prepared as shown in Figure 1. Figure 2 shows the developed products after frying.

\section{Texture properties}

Regarding texture, it was found that the texture was significantly influenced by the ingredients of the kluiklui (Table 2). FEK5 prepared with 4\% type-3 resistant starch banana flour, and 1\% porang glucomannan had the highest $(p<0.05)$ hardness with the lowest fracturability values. In 
general, when both flours were applied to the formulation, kluiklui's hardness and brittleness values increased. Apart from the cooking conditions, hardness and other textural attributes can be influenced by the flour's type, quantity, and content (Gaines, 1993). The result suggests that FEK5 would be suitable for maintaining its shape during transportation and would easily fracture when chewed in the mouth (Manley, 2001).

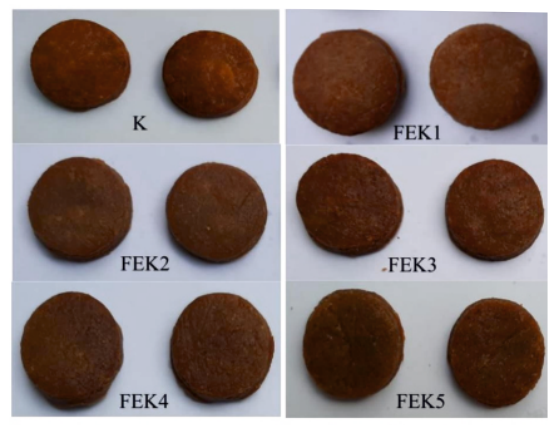

Figure 2. Developed products

\section{Color Attributes}

The comparison of color properties among all samples was performed and shown in Table 2 . There was a significant difference between products for some color parameters. The lightness of the products was significantly higher in the $\mathrm{K}$, while it was significantly lower in all flour-enriched kluiklui.
Flour enriched kluiklui produced with the addition of porang glucomannan, unripe banana flour, type-3 resistant starch banana flour, and their mixtures appeared to show no difference concerning the lightness. The $a^{*}$ values, with all measurements, confirm that the red tone is dominating over the green in all samples. However, red tone was significantly more expressed and detected for the control sample, while FEK 3 produced with type- 3 resistant starch had significantly less expressed red tone. The $b^{*}$ values for all samples high above zero confirmed that the yellow tone dominated over the blue in all samples, with the yellow tone being more expressed than the red tone. The intensity of the yellow tone differed regarding the sample composition. The most expressed yellow tone was detected in the control sample, while the less expressed yellow tone was detected in FEK3.

Significantly the higher hue values indicate yellow tone while lower hue values indicate red tone in the product. In comparison to hue value, the kluiklui produced with blend flour addition had completely different colors than the control one and produced only with one type of flour. The color changed to dark brown with the incorporation of flour. It may be due to the ingredient composition, Maillard reaction or nonenzymatic browning, which depends on reducing sugars and amino acids or proteins on the surface, cooking temperature, and time as explained by Pereira et al., (2013).

Table 2. Texture properties and color attributes of formulated kluikluis

\begin{tabular}{llllllll}
\hline \multicolumn{6}{c}{ Texture properties } & \multicolumn{5}{c}{ Color attributes } \\
\hline & Hardness (N) & Fracturability & $\mathbf{L}^{*}$ & $\mathbf{a}^{*}$ & $\mathbf{b}^{*}$ & $\Delta \mathrm{E}^{\star}$ & $\mathbf{h}^{\circ}$ \\
\hline K & $133.50 \pm 34.32^{\mathrm{a}}$ & $8.25 \pm 1.51^{\mathrm{c}}$ & $53.35 \pm 0.35^{\mathrm{b}}$ & $13.26 \pm 0.14^{\mathrm{c}}$ & $23.42 \pm 0.55^{\mathrm{d}}$ & $46.92 \pm 0.17^{\mathrm{a}}$ & $60.44 \pm 0.38^{\mathrm{ab}}$ \\
FEK1 & $222.16 \pm 42.54^{\mathrm{b}}$ & $6.09 \pm 1.13^{\mathrm{abc}}$ & $51.53 \pm 0.35^{\mathrm{a}}$ & $11.80 \pm 0.20^{\mathrm{b}}$ & $21.52 \pm 0.06^{\mathrm{c}}$ & $47.24 \pm 0.28^{\mathrm{a}}$ & $61,26 \pm 0.45^{\mathrm{ab}}$ \\
FEK2 & $235.95 \pm 9.81^{\mathrm{bc}}$ & $6.9 \pm 1.08^{\mathrm{bc}}$ & $51.05 \pm 0.92^{\mathrm{a}}$ & $11.29 \pm 0.54^{\mathrm{ab}}$ & $20.66 \pm 1.20^{\mathrm{bc}}$ & $47.23 \pm 0.22^{\mathrm{a}}$ & $61.26 \pm 0.38^{\mathrm{ab}}$ \\
FEK3 & $267.48 \pm 10.17^{\mathrm{bc}}$ & $4.39 \pm 0.49^{\mathrm{ab}}$ & $49.89 \pm 0.53^{\mathrm{a}}$ & $10.53 \pm 0.20^{\mathrm{a}}$ & $18.64 \pm 0.40^{\mathrm{a}}$ & $47.03 \pm 0.30^{\mathrm{a}}$ & $60.51 \pm 0.56^{\mathrm{ab}}$ \\
FEK4 & $283.17 \pm 38.77^{\mathrm{bc}}$ & $6.36 \pm 0.80^{\mathrm{bc}}$ & $50.88 \pm 0.26^{\mathrm{a}}$ & $11.38 \pm 0.16^{\mathrm{ab}}$ & $21.24 \pm 0.26^{\mathrm{c}}$ & $47.52 \pm 0.24^{\mathrm{a}}$ & $61.82 \pm 0.56^{\mathrm{b}}$ \\
FEK5 & $317.12 \pm 12.32^{\mathrm{c}}$ & $3.13 \pm 0.45^{\mathrm{a}}$ & $50.20 \pm 0.59^{\mathrm{a}}$ & $10.93 \pm 0.29^{\mathrm{ab}}$ & $19.22 \pm 0.57^{\mathrm{ab}}$ & $47.25 \pm 031^{\mathrm{a}}$ & $60.35 \pm 0.24^{\mathrm{a}}$ \\
\hline
\end{tabular}

Notes:

Values in the table are the mean with standard deviation $( \pm)$ of triplicate determinations. Values followed by the same superscript(s) within the same column are not significantly different at (Duncan's test, $\mathrm{p}<0.05$ ).

$\mathrm{K}=100 \%$ partially defatted peanut paste, FEK $1=$ with $1 \%$ of glucomannan, FEK 2 : with $5 \%$ of unripe banana flour, FEK $3=$ with $5 \%$ of RS-3 banana flour, FEK $4=$ with $4 \%$ of unripe banana flour and $1 \%$ of glucomannan, FEK5 = with $4 \%$ of RS-3 banana flour and $1 \%$ of glucomannan.

$\mathrm{L}^{*}=$ Lightness $(+)$ blackness (-); $\mathrm{a}^{*}=$ Redness $(+)$ and greenness $(-) ; \mathrm{b}^{*}=$ Yellowness $(+)$ and blueness $(-) ; \Delta \mathrm{E}=$ Total color change

\section{Nutritional properties of kluiklui formulated}

The final products with the control showed an interesting nutritional composition (Table 3). The moisture content ranged from 6.39 percent for control to 9.3 percent for FEK2. The control one had lower moisture than flour-enriched kluiklui. It was observed that the moisture has increased when flour was added in the formulation. We note that the adding of the banana flour and porang glucomannan had influenced the moisture and could also influence some stability characteristics and the final product's shelf-life as concluded by the results of Sanya et al., (2013). This high level of moisture in flour-enriched kluiklui can be attributed to the water holding capacity of flours used, which retained higher moisture content in the flour-enriched kluiklui formulated and could have contributed to a change in the moisture content during frying.

The ash content observed ranged from 3.62 to $3.7 \%$ in all treatments (Table 3). The addition of the flours in the formulation did not influence the mineral content of the final products. The amount of remaining oil recommended having a good kluiklui and frying would be the consequence of high-fat content in the final product. The fat content ranged from 26.42 to $31.95 \%$ and was lower in control one $(26.42)$ than others (Table 3). The highest fat content observed while substitution was applied may be due to the flours' holding capacity, which retained fat during frying. Porang glucomannan and banana flour have originally low-fat contents. the increased fat content in the final product is a consequence of frying. 
The protein content was lower in flour-enriched kluiklui than control and was also interestingly i.e. $>30 \%$. The main ingredient of kluiklui is peanut, which is a high source of protein. It is expected that the protein content must be high in the final product. In developing countries, foods rich in protein content are of great nutritional importance and are required for children to grow, repair, and maintain the body (Mahan \& Escott-Stump, 2008). The lower protein content in all flour-enriched kluiklui can be attributed to flour addition. Considering the cooking processes of the products (flour extrusion and heating) and the high content of fibers in the flours, it was expected that the protein content was reduced.
The flour samples used in this study are considered as starchy foods. The final products had carbohydrate content ranging from $23.83 \%-29.33 \%$. The carbohydrate content was lower in the flour-enriched kluiklui than in the control. Energy content is the number of calories available from food through oxidation, and it is a function of the total protein, fat, and carbohydrates present in the food. The final products can be considered as a good source of energy. This energy value remains high despite the addition of porang glucomannan or banana flour. The energy content of the kluiklui samples was within the range of $487.14-511.97 \mathrm{kcal} / \mathrm{g}$. The calorie value is considered to be high, and thus, flour-enriched kluiklui can be applied in the diet as an energetic food.

Table 3. Nutritional properties of formulated kluikluis (\%)

\begin{tabular}{lllllll}
\hline & Moisture & Ash & Fat & Protein & CHO & Energy \\
\hline K & $6.39 \pm 0.18^{\mathrm{a}}$ & $3.7 \pm 0.02^{\mathrm{a}}$ & $26.42 \pm 0.09^{\mathrm{a}}$ & $34.16 \pm 0.36^{\mathrm{b}}$ & $29.33 \pm 0.43^{\mathrm{d}}$ & $491.79 \pm 0.76^{\mathrm{a}}$ \\
FEK1 & $7.21 \pm 0.06^{\mathrm{b}}$ & $3.7 \pm 0.01^{\mathrm{a}}$ & $29.17 \pm 0.08^{\mathrm{bc}}$ & $32.57 \pm 0.29^{\mathrm{a}}$ & $27.36 \pm 0.3^{\mathrm{c}}$ & $502.3 \pm 0.58^{\mathrm{b}}$ \\
FEK2 & $9.3 \pm 0.09^{\mathrm{e}}$ & $3.65 \pm 0.03^{\mathrm{a}}$ & $27.78 \pm 0.23^{\mathrm{b}}$ & $32.93 \pm 0.43^{\mathrm{a}}$ & $26.35 \pm 0.44^{\mathrm{bc}}$ & $487.14 \pm 1.19^{\mathrm{a}}$ \\
FEK3 & $8.7 \pm 0.00^{\mathrm{d}}$ & $3.62 \pm 0.01^{\mathrm{a}}$ & $27.49 \pm 0.16^{\mathrm{a}}$ & $33.04 \pm 0.2^{\mathrm{a}}$ & $27.15 \pm 0.21^{\mathrm{bc}}$ & $488.16 \pm 0.8^{\mathrm{a}}$ \\
FEK4 & $8.31 \pm 0.00^{\mathrm{c}}$ & $3.64 \pm 0.01^{\mathrm{a}}$ & $31.95 \pm 1.19^{\mathrm{d}}$ & $32.26 \pm 0.32^{\mathrm{a}}$ & $23.83 \pm 1.25^{\mathrm{a}}$ & $511.97 \pm 5.9^{\mathrm{c}}$ \\
FEK5 & $8.5 \pm 0.2^{\text {cd }}$ & $3.66 \pm 0.03^{\mathrm{a}}$ & $29.97 \pm 0.19^{\mathrm{c}}$ & $32.52 \pm 0.31^{\mathrm{a}}$ & $25.35 \pm 0.33^{\mathrm{b}}$ & $501.22 \pm 1.66^{\mathrm{b}}$ \\
\hline
\end{tabular}

Notes:

Values in the table are the mean with standard deviation $( \pm)$ of triplicate determinations. Values followed by the same superscript(s) within the same column are not significantly different at (Duncan's test, $\mathrm{p}<0.05$ ).

$\mathrm{K}=100 \%$ partially defatted peanut paste, FEK $1=$ with $1 \%$ of glucomannan, FEK 2 : with $5 \%$ of unripe banana flour, FEK $3=$ with $5 \%$ of RS-3 banana flour, FEK $4=$ with $4 \%$ of unripe banana flour and $1 \%$ of glucomannan, FEK $5=$ with $4 \%$ of RS-3 banana flour and $1 \%$ of glucomannan.

\section{Sensory properties}

The products were evaluated for their sensory acceptability of each attribute (Table 4). All formulation samples were considered to be acceptable by the panelists. Taste is an important attribute in the acceptance of food products. In terms of aroma and taste scores, there did not seem to be any difference despite the presence of banana flour. This could be explained by the fact that the smell of peanuts was so strong that it could cover the smell of bananas. The mean scores for the overall acceptability of FEK 1 and FEK5 were significantly higher than that of control. The incorporation of porang and type- 3 resistant starch banana flour improved the texture as indicated by the instrumental texture profile analysis regarding the fracturability. The result showed a nonsignificant difference for overall acceptability. FEK1 and FEK5 were found to be higher than the control sample i.e., 5.53 and 5.40, respectively. Regarding the single mixes from suggested ingredients, FEK1 had excellent acceptable scores. In double mixes from suggested ingredients, FEK 5 seems the most appreciated. FEK5 was liked very much than others regarding the commentary of all panelists. The low score of FEK 5 in terms of appearance and color could be explained by the color of the BFRS3 flour which was very similar to chocolate.

Table 4. Sensory evaluation of flour-enriched kluikluis

\begin{tabular}{lllllll}
\hline & Appearence & Texture & Color & Aroma & Taste & Overall \\
\hline K & $4.93 \pm 0.21^{\mathrm{a}}$ & $4.03 \pm 0.22^{\mathrm{a}}$ & $5.13 \pm 0.22^{\mathrm{b}}$ & $5.43 \pm 0.19^{\mathrm{a}}$ & $4.83 \pm 0.23^{\mathrm{a}}$ & $4.93 \pm 0.21^{\mathrm{a}}$ \\
FEK1 & $5.43 \pm 0.23^{\mathrm{a}}$ & $4.80 \pm 0.29^{\mathrm{b}}$ & $5.93 \pm 0.14^{\mathrm{c}}$ & $5.47 \pm 0.20^{\mathrm{a}}$ & $5.23 \pm 0.18^{\mathrm{a}}$ & $5.53 \pm 0.20^{\mathrm{a}}$ \\
FEK2 & $5.17 \pm 0.18^{\mathrm{a}}$ & $4.97 \pm 0.21^{\mathrm{bc}}$ & $5.13 \pm 0.21^{\mathrm{b}}$ & $5.43 \pm 0.12^{\mathrm{a}}$ & $5.00 \pm 0.24^{\mathrm{a}}$ & $5.07 \pm 0.20^{\mathrm{a}}$ \\
FEK3 & $4.83 \pm 0.19^{\mathrm{a}}$ & $5.20 \pm 0.28^{\mathrm{bc}}$ & $4.63 \pm 0.24^{\mathrm{a}}$ & $5.13 \pm 0.19^{\mathrm{a}}$ & $5.00 \pm 0.24^{\mathrm{a}}$ & $5.00 \pm 0.21^{\mathrm{a}}$ \\
FEK4 & $5.40 \pm 0.21^{\mathrm{a}}$ & $4.83 \pm 0.27^{\mathrm{b}}$ & $5.50 \pm 0.21^{\mathrm{bc}}$ & $5.53 \pm 0.13^{\mathrm{a}}$ & $4.87 \pm 0.13^{\mathrm{a}}$ & $5.00 \pm 0.20^{\mathrm{a}}$ \\
FEK5 & $4.90 \pm 0.20^{\mathrm{a}}$ & $5.60 \pm 0.22^{\mathrm{c}}$ & $4.80 \pm 0.21^{\mathrm{a}}$ & $5.23 \pm 0.20^{\mathrm{a}}$ & $5.20 \pm 0.18^{\mathrm{a}}$ & $5.40 \pm 0.17^{\mathrm{a}}$ \\
\hline
\end{tabular}

Notes:

Values in the table are the mean with standard deviation $( \pm)$ of triplicate determinations. Values followed by the same superscript(s) within the same column are not significantly different at (Duncan's test, $\mathrm{p}<0.05$ ).

$\mathrm{K}=100 \%$ partially defatted peanut paste, FEK $1=$ with $1 \%$ of glucomannan, FEK 2 : with $5 \%$ of unripe banana flour, FEK $3=$ with $5 \%$ of RS-3 banana flour, FEK $4=$ with $4 \%$ of unripe banana flour and $1 \%$ of glucomannan, FEK5 = with $4 \%$ of RS-3 banana flour and $1 \%$ of glucomannan. 


\section{Indigestible fraction of kluiklui}

The indigestible fraction (IF) consists of those food constituents that are unavailable for digestion in the small intestine and pass into the colon, where the fermentative microflora may further process them. According to SauraCalixto et al., (2000), the soluble indigestible fraction (SIF) comprises monosaccharides, disaccharides and oligosaccharides, whilst the insoluble indigestible fraction
(IIF) includes RS, indigestible protein, polyphenols and nonstarch polysaccharides (cellulose, hemicellulose and lignin). The indigestible fraction (IF) was analyzed in kluikluis sample after defatting, which excludes the effect of oil content in the formulation, the IIF and the SIF increased by the incorporation of banana flour and porang glucomannan (Table 5).

Table 5. Indigestible fractions of kluiklui formulated

\begin{tabular}{llll}
\hline Sample & IIF & SIF & TIF $^{*}$ \\
\hline K & $18.73 \pm 0.15^{\mathrm{a}}$ & $2.62 \pm 0.16^{\mathrm{a}}$ & $21.35 \pm 0.06^{\mathrm{a}}$ \\
FEK1 & $22.59 \pm 0.13^{\mathrm{b}}$ & $5.10 \pm 0.51^{\mathrm{b}}$ & $27.69 \pm 0.44^{\mathrm{b}}$ \\
FEK2 & $24.02 \pm 0.40^{\mathrm{b}}$ & $4.77 \pm 0.62^{\mathrm{b}}$ & $28.79 \pm 0.30^{\mathrm{b}}$ \\
FEK3 & $25.41 \pm 0.67^{\mathrm{b}}$ & $5.13 \pm 0.22^{\mathrm{b}}$ & $30.53 \pm 0.51^{\mathrm{b}}$ \\
FEK4 & $24.27 \pm 0.25^{\mathrm{b}}$ & $5.83 \pm 0.07^{\mathrm{b}}$ & $30.10 \pm 0.29^{\mathrm{b}}$ \\
FEK5 & $24.7 \pm 2.91^{\mathrm{b}}$ & $6.06 \pm 0.5^{\mathrm{b}}$ & $30.76 \pm 3.47^{\mathrm{b}}$ \\
\hline
\end{tabular}

Notes:

Values in the table are the mean with standard deviation $( \pm)$ of triplicate determinations. Values followed by the same superscript(s) within the same column are not significantly different at (Duncan's test, $\mathrm{p}<0.05$ ).

$\mathrm{K}=100 \%$ partially defatted peanut paste, FEK $1=$ with $1 \%$ of glucomannan, FEK 2 : with $5 \%$ of unripe banana flour, FEK3 = with $5 \%$ of RS-3 banana flour, FEK $4=$ with $4 \%$ of unripe banana flour and $1 \%$ of glucomannan, FEK5 = with $4 \%$ of RS-3 banana flour and $1 \%$ of glucomannan.

$\mathrm{SIF}=$ Soluble Indigestible fraction; $\mathrm{IIF}=$ indigestible insoluble fraction; $\mathrm{TIF}=$ total indigestible fraction;

* Values calculated as the addition between IIF and SIF.

The indigestible fraction (IF) consists of those food constituents that are unavailable for digestion in the small intestine and pass into the colon, where the fermentative microflora may further process them. According to SauraCalixto et al., (2000), the soluble indigestible fraction (SIF) comprises monosaccharides, disaccharides and oligosaccharides, whilst the insoluble indigestible fraction (IIF) includes RS, indigestible protein, polyphenols and non-starch polysaccharides (cellulose, hemicellulose and lignin). The indigestible fraction (IF) was analyzed in kluikluis sample after defatting, which excludes the effect of oil content in the formulation, the IIF and the SIF increased by the incorporation of banana flour and porang glucomannan (Table 5).

When all kluiklui samples are compared, it showed higher total insoluble fraction (TIF) content compared to control $(\mathrm{K})$, which could in principle, be related to the higher RS content of UBF and BFRS3 and higher DF content in glucomannan, as reported previously. FEK3, FEK4, and FEK 5 showed the highest TIF, which could be the result of the presence of type 3 resistant starch in the FEK3 sample or interactions of the resistant starch fractions from banana flour and dietary fiber in glucomannan and others protein and non-starch polysaccharides present in FEK4 or interactions of the type 3 resistant starch fractions from BFRS3 and dietary fiber in glucomannan and others protein and nonstarch polysaccharides present in FEK5. The main component of the indigestible material in the kluiklui was the insoluble fraction, being higher in the incorporation of banana flour. FEK5 also shows the highest SIF and, therefore, a high total IF content.

The control sample $(\mathrm{K})$ had the lowest IIF and SIF value. Kluiklui with single incorporation of porang glucomannan
(FEK1) or native banana flour (FEK2) or type 3 resistant starch banana flour (FEK3) showed differences in values of IIF and SIF even its not significant.

According to Saura-Calixto et al., (2000), the increase in the IIF in the sample with UBF and BFRS3 is related to the high content of this fraction in the banana flour, same explanation with the incorporation of porang glucomannan that showed a raise in FEK1 sample, and the low values in the SIF were related with the cooking loss value, because the SIF fraction comprises single sugars and oligosaccharide, which were solubilized during cooking. Wanting to increase the indigestible portion will lead us to increase the incorporation of the unripe banana flour and porang glucomannan in the preparation, according to Ovando-Martinez et al., (2009). No significant difference was found between all flour enriched kluiklui samples. The type of flour and the rate of incorporation used for kluiklui preparation could be responsible for this pattern.

\section{CONCLUSION}

Overall, incorporating porang glucomannan and banana flour in kluiklui formulation is possible to improve the recipe of original kluiklui, although they need to be optimized regarding their effect on many characteristics such as sensory, nutritional, functional, and texture. As the flour-enriched kluiklui is in the development stage, we need further research to determine many necessary and useful variables for production. The present study indicates that FEK 5 containing porang glucomannan and type-3 resistant starch banana flour hold good promise concerning nutritional values with a good portion of indigestible fraction, and so achieved successful enrichment. The flour-enriched kluiklui can be developed as a product with an excellent functional food grade. 


\section{ACIKNOWLEDGEMENT}

We appreciate team glucomannan FTP/UGM for providing glucomannan powder for the study and extraction technology.

\section{REFERENCES}

Agbaje, R., Hassan, C. Z., Arifin, N., \& Rahman, A. A. (2014). Sensory Preference and Mineral Contents of Cereal Bars Made From Glutinous Rice Flakes and Sunnah Foods. IOSR Journal of Environmental Science, Toxicology and Food Technology, 8(12), 26-31.https://doi.org/10.9790/2402-081222631

Aparicio-Saguilán, A., Flores-Huicochea, E., Tovar, J., García-Suárez, F., Gutiérrez-Meraz, F., \& Bello-Pérez, L. A. (2005). Resistant starchrich powders prepared by autoclaving of native and lintnerized banana starch: Partial characterization. Starch/Staerke, 57(9), 405-412. https://doi.org/10.1002/star.200400386

Barreira, J. C. M., Nunes, M. A., da Silva, B. V., Pimentel, F. B., Costa, A. S. G., Alvarez-Ortí, M., ... Oliveira, M. B. P. P. (2019). Almond coldpressed oil by-product as ingredient for cookies with potential health benefits: Chemical and sensory evaluation. Food Science and Hum $a$ Wellness, 8 ( 3), $292-298$. https://doi.org/10.1016/j.fshw.2019.07.002

Chua, M., Baldwin, T. C., Hocking, T. J., \& Chan, K. (2010). Traditional uses and potential health benefits of Amorphophallus konjac K. Koch ex N.E.Br. Journal of Ethnopharmacology, 128(2), 268-278. https://doi.org/10.1016/j.jep.2010.01.021

Cui, T., Wu, T., Liu, R., Sui, W., Wang, S., \& Zhang, M. (2019). Effect of Degree of Konjac Glucomannan Enzymatic Hydrolysis on the Physicochemical Characteristic of Gluten and Dough [Researcha r ticle]. ACS Omega, 4 (6), $9654-9663$. https://doi.org/10.1021/acsomega.9b00061

da Mota, R. V, Lajolo, F. M., Ciacco, C., \& Cordenunsi, B. R. (2000). Composition and Functional Properties of Banana Flour from Different Varieties. Starch/Stärke, 52(2-3), 63-68.

Englyst, H. N., Kingman, S. M., \& Cummings, J. H. (1992). Classification and measurement of nutritionally important starch fractions. European Journal of Clinical Nutrition, 46(SUPPL. 2). https://doi.org/10.1016/S0271-5317(97)00010-9

Faisant, N., Buléon, A., Colonna, P., Molis, C., Lartigue, S., Galmiche, J. P., \& Champ, M. (1995). Digestion of raw banana starch in the small intestine of healthy humans: structural features of resistant starch. British Journal of Nutrition, 73(1), 111-123. https://doi.org/10.1079/bjn19950013

Fekria, A. M., Isam, A. M. A., Suha, O. A. and Elfadil, E. B. 2012 Nutritional and functional characterization of deffated seed cake flour of two Sudanese groundnut (Arachishypogaea). Int Fd Res J 12: 629-37.

Gaines, C. S. (1993). Collaborative studies on baking quality of cookies flour by wire-cut formulation. Cereal Foods World, 38, 26-30.

Harmayani, E., Aprilia, V., \& Marsono, Y. (2014). Characterization of glucomannan from Amorphophallus oncophyllus and its prebiotic activity in vivo. Carbohydrate Polymers, 112, 475-479.

Iwe, M.O. (2014). Current trends in sensory evaluation of foods. Rejoin Communication Services Ltd Uwani Enugu. pp. 142-145.

Kaur, P., Sharma, P., Kumar, V., Panghal, A., Kaur, J., \& Gat, Y. (2018). Effect of addition of flaxseed flour on phytochemical, physicochemical, nutritional, and textural properties of cookies. Journal of the Saudi Society of Agricultural Sciences, 18(4), 372-377. https://doi.org/10.1016/j.jssas.2017.12.004

Khouryieh, H., \& Aramouni, F. (2013). Effect of flaxseed flour incorporation on the physical properties and consumer acceptability of cereal bars. Food Science and Technology International, 19(6), 549-556. https://doi.org/10.1177/1082013212462231

Magallanes-Cruz, P. A., Bello-Pérez, L. A., Agama-Acevedo, E., Tovar, J., \& Carmona-Garcia, R. (2020). Effect of the addition of thermostable and non-thermostable type 2 resistant starch (RS2) in cake batters. Lwt-Food Science and Technology Journal, 118, 1-9. https://doi.org/10.1016/j.lwt.2019.108834

Mahloko, L. M., Silungwe, H., Mashau, M. E., \& Kgatla, T. E. (2019). Bioactive compounds, antioxidant activity and physical characteristics of wheat-prickly pear and banana biscuits. Heliyon, 5(10), e02479. https://doi.org/10.1016/j.heliyon.2019.e02479

Manley, D. (2001). Biscuit, cracker and cookie recipes for the food industry. Cambridge, UK: Woodhead Publishing Limited.

Ovando-Martinez, M., Sáyago-Ayerdi, S., Agama-Acevedo, E., Goñi, I., \& Bello-Pérez, L. A. (2009). Unripe banana flour as an ingredient to increase the undigestible carbohydrates of pasta. Food Chemistry, 113(1),121-126. https://doi.org/10.1016/j.foodchem.2008.07.035

Pereira, D., Correia, P. M. R., \& Guiné, R. P. F. (2013). Analysis of the physical-chemical and sensorial properties of Maria type cookies. Acta Chimica Slovaca, 6(2), 269-280. https://doi.org/10.2478/acs2013-0040
ISanya, Emile A., Ahouannou, C., Chaffa, G., \& Soumanou, M. M. (2013) Effects of added Maize Flour on Physicomechanical Properties of Benin Patties made of Defatted dough of Groundnut Seeds "Arachis hypogaea ." International Journal of Current Research, 5(2), 212-218.

Sanya, Emile Adjibadé, Ahouannou, C., Chaffa, G., \& Ahouansou, R. (2015). Effects of torrefaction on some physico-mechanical and organoleptic characteristics of maize flour blended peanut patties rolled into sticks in Benin. International Journal of Biological and Chemical Sciences, 9(3), 1440-1458.

Saura-Calixto, F., Garcia-Alonso, A., Goni, I., \& Bravo, L. (2000). In vitro determination of the indigestible fraction in foods: An alternative to dietary fiber analysis. Journal of Agricultural and Food Chemistry, 48(8), 3342-3347. https://doi.org/10.1021/jf0000373

Videgla, E. G., Floquet, A., Mongbo, R., Garba, K., \& Tossou, H. S. (2016) Liens à l'origine et qualité spécifique d'un produit de l'artisanat agroalimentaire du Bénin - le kluiklui d'Agonlin. Cahiers Agricultures, 25. https://doi.org/10.1051/cagri/2016016

Xiong, G., Cheng, W., Ye, L., Du, X., Zhou, M., Lin, R., ... Cai, Y. Z. (2009). Effects of konjac glucomannan on physicochemical properties of myofibrillar protein and surimi gels from grass carp (Ctenopharyngodon idella). Food Chemistry, 116(2), 413-418. https://doi.org/10.1016/j.foodchem.2009.02.056

Zhou, Y., Cao, H., Hou, M., Nirasawa, S., Tatsumi, E., Foster, T. J., \& Cheng, Y. (2013). Effect of konjac glucomannan on physical and sensory properties of noodles made from low-protein wheat flour. Food Research International, 51 (2), 879-885. https://doi.org/10.1016/j.foodres.2013.02.002 